\title{
An unusually stable chlorophosphite: What makes BIFOP-CI so robust against hydrolysis?
}

\author{
Roberto Blanco Trillo, Jörg M. Neudörfl and Bernd Goldfuss *
}

\author{
Full Research Paper \\ Address: \\ Department for Chemistry, Institut für Organische Chemie, Universität \\ zu Köln, Greinstr. 4, 50939 Köln, Germany

\section{Email:} \\ Bernd Goldfuss* - goldfuss@uni-koeln.de \\ * Corresponding author \\ Keywords: \\ chirality; hydrolysis; phosphorus; rearrangements; terpenoids
}

\author{
Beilstein J. Org. Chem. 2015, 11, 313-322. \\ doi:10.3762/bjoc. 11.36 \\ Received: 11 September 2014 \\ Accepted: 11 February 2015 \\ Published: 04 March 2015 \\ Associate Editor: J. A. Murphy \\ (c) 2015 Blanco Trillo et al; licensee Beilstein-Institut. \\ License and terms: see end of document.
}

\begin{abstract}
Two chlorophosphites, the biphenyl-based BIFOP-Cl and the diphenyl ether-based $\mathrm{O}-\mathrm{BIFOP}-\mathrm{Cl}$, exhibit striking differences regarding their reaction with water. While $\mathrm{BIFOP}-\mathrm{Cl}$ is nearly completely unreactive, its oxo-derivative $\mathrm{O}-\mathrm{BIFOP}-\mathrm{Cl}$ reacts instantly with water, yielding a tricyclic hydrocarbon unit after rearrangement. The analysis of the crystal structure of $\mathrm{O}-\mathrm{BIFOP}-\mathrm{Cl}$ and $\mathrm{BIFOP}-\mathrm{Cl}$ revealed that the large steric demand of encapsulating fenchane units renders the phosphorus atom nearly inaccessible by nucleophilic reagents, but only for BIFOP-Cl. In addition to the steric effect, a hypervalent $\mathrm{P}(\mathrm{III})-\mathrm{O}$ interaction as well as an electronic conjugation effect causes the high reactivity of $\mathrm{O}-\mathrm{BIFOP}-\mathrm{Cl}$. A DFT study of the hydrolysis in $\mathrm{BIFOP}-\mathrm{Cl}$ verifies a higher repulsive interaction to water and a decreased leaving tendency of the chloride nucleofuge, which is caused by the fenchane units. This high stability of BIFOP-Cl against nucleophiles supports its application as a chiral ligand, for example, in Pd catalysts.
\end{abstract}

\section{Introduction}

Phosphorus halides are highly reactive intermediates for the synthesis of phosphites and phosphoramidites [1-5], which are widely used, for example, as ligands in catalysts [6-9]. There are also some applications of phosphine halides used as ligands in catalytic reactions, for example, in cross-coupling reactions and hydroformylations [10-12]. We recently reported the application of the fenchole-based, phosphine halide BIFOP-Hal $(\mathrm{Hal}=\mathrm{F}, \mathrm{Cl}, \mathrm{Br})($ Scheme 1) in an intramolecular palladiumcatalyzed alkyl-aryl cross-coupling reaction [13] and in Pd-catalyzed allylic substitutions [14]. Several of the highly sterically hindered BIFOP derivatives were employed as ligands in $\mathrm{Cu}$-catalyzed 1,4-additions [15]. Similar chelating fencholates [16-22] (Scheme 1) were employed in enantioselective organozinc catalysis reactions [23-26], umpolung catalysis [27] and in organoaluminum [17] and chiral $n$-butyllithium aggregates [28-33].

The chlorophosphite BIFOP-Cl (1) is air-stable and very resistant to hydrolysis (Scheme 2) $[13,15]$. The low reactivity of $\mathbf{1}$ to $\mathrm{O}$ - and $\mathrm{C}$-nucleophiles is explained by the tight encapsulation of the $\mathrm{P}-\mathrm{Cl}$ unit of the endo-fenchane moieties [15]. This unusual stability of the BIFOP-halides prompted the comparison of 
<smiles>[R]c1cc([R])nc(OC2(OP)C3CCC2(C)CC3)c1</smiles>

Fenchylphosphinites FENOPs

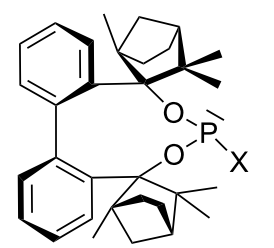

$\mathrm{X}=\mathrm{H}, \mathrm{F}, \mathrm{Cl}, \mathrm{Br}$

$\mathrm{Me}, \mathrm{Et}, n-\mathrm{Bu}$,

$t$-Bu, $\mathrm{Ph}, \mathrm{OPh}, \mathrm{NEt}_{2}$, anisyl, $\mathrm{O} t-\mathrm{Bu}$

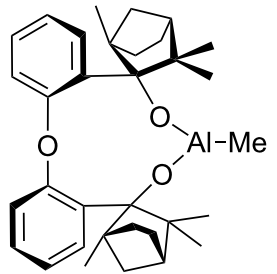

Diphenyl ether-2,2'-bisfenchol aluminium

O-BIFOL-AI
O-BIFOP-Cl, 3

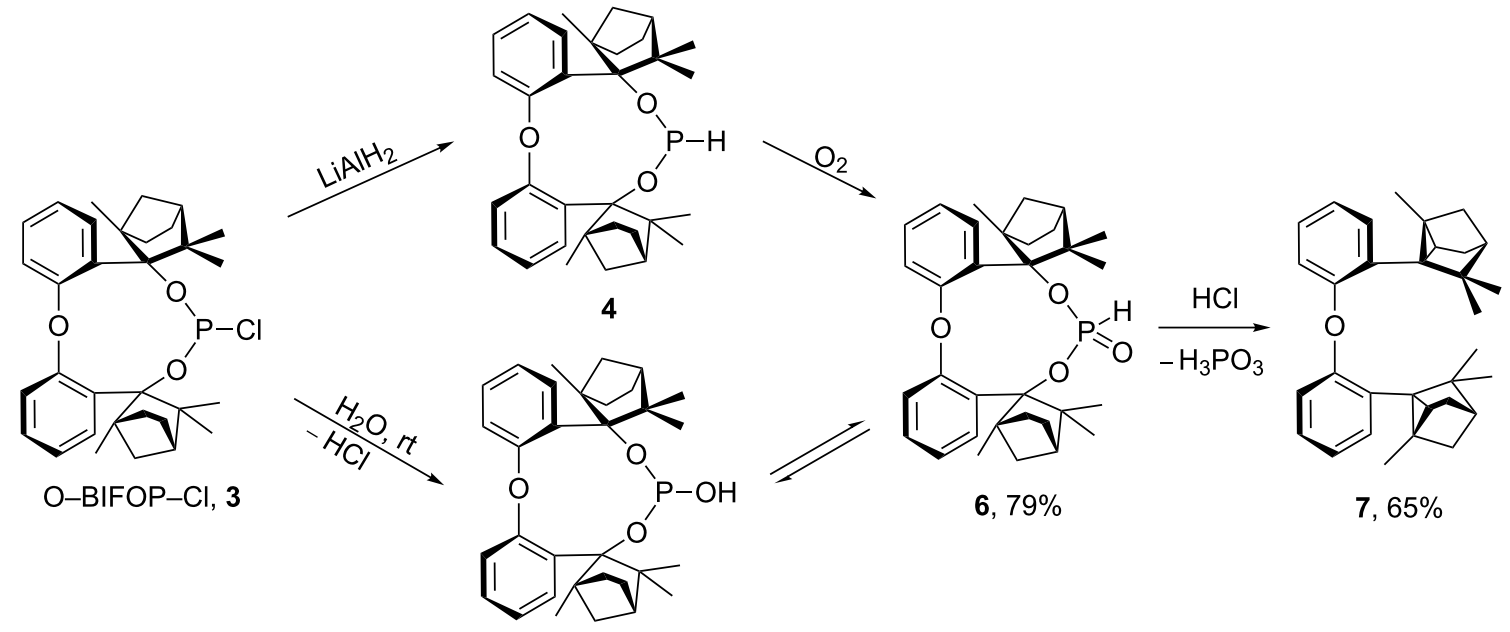

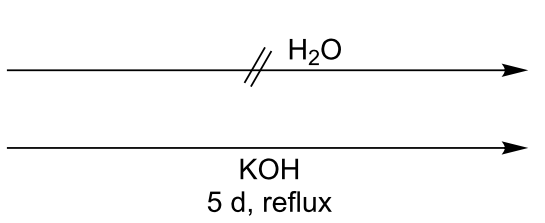

d, reflux

BIFOP-CI, 1

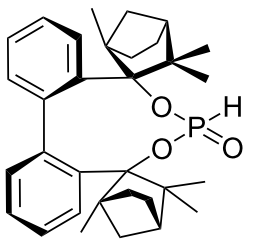

2, $98 \%$

5

Scheme 2: Reaction of BIFOP-Cl (1) to BIFOP-(O)H (2) and of O-BIFOP-Cl (3) yielding O-BIFOP-H (4), O-BIFOP-(O)H (6) as well as diphenyl ether-2,2'-biscyclofenchene 7

$\mathrm{BIFOP}-\mathrm{Cl}$ (1) with its diphenyl ether derivative $\mathrm{O}-\mathrm{BIFOP}-\mathrm{Cl}$

(3). Despite similar encapsulation by two fencholate moieties, O-BIFOP-Cl 3 exhibits a significantly higher reactivity with nucleophiles (e.g., with water). Here we rationalize the different reactivities of $\mathbf{1}$ and $\mathbf{3}$.

\section{Results and Discussion}

In contrast to BIFOP-Cl (1), the diphenyl ether analogue $\mathrm{O}-\mathrm{BIFOP}-\mathrm{Cl}(\mathbf{3})$ exhibits the expected halophosphite reactivity and instantly reacts with water (Scheme 2, Figure 1). NMR monitoring of the hydrolysis showed that $\mathrm{O}-\mathrm{BIFOP}-\mathrm{Cl}$ (3, ${ }^{31} \mathrm{P}$ NMR, $\delta=161.9$, Figure 1$)$ is immediately hydrolyzed, yielding $\mathrm{O}-\mathrm{BIFOP}-(\mathrm{O}) \mathrm{H}\left(\mathbf{6},{ }^{31} \mathrm{P}\right.$ NMR, $\delta=-8.2$, Figure 1$)$. After $37 \mathrm{~min}$, the amount of starting $\mathrm{O}-\mathrm{BIFOP}-\mathrm{Cl}(\mathbf{3})$ as well as the primary hydrolysis product 6 (Figure 1) is nearly completely depleted. The details of the reaction mixture that yielded diphenyl ether-2,2'-biscyclofenchene 7 (Figure 2) are shown in Scheme 2. 


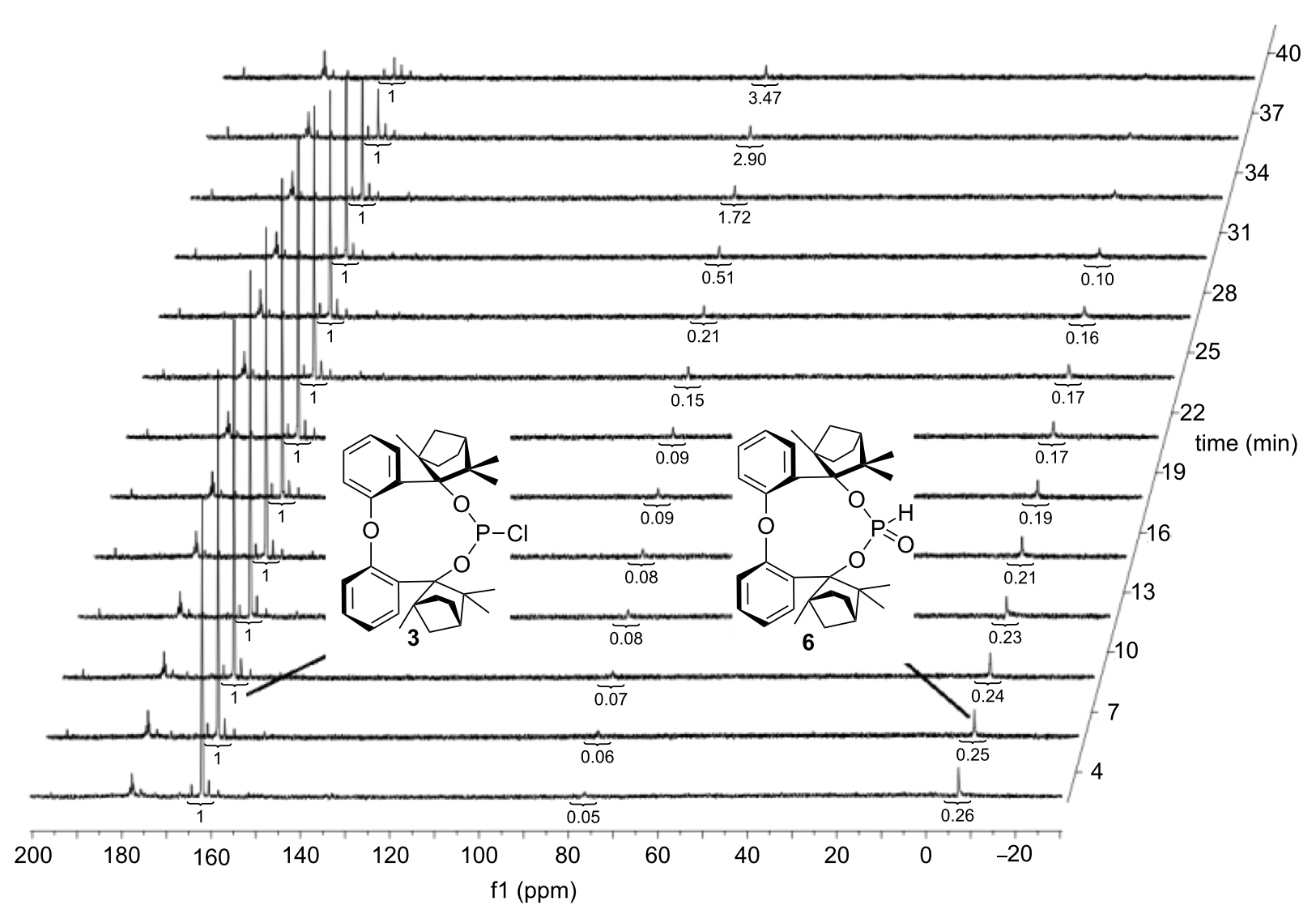

Figure 1: ${ }^{31} \mathrm{P}$ NMR $\left(125 \mathrm{MHz}, \mathrm{CDCl}_{3}\right)$ of O-BIFOP-Cl $(3, \delta=161.9)$ after the addition of 1 equiv $\mathrm{H}_{2} \mathrm{O}$ and formation of O-BIFOP-(O)H $(6, \delta=-8.2)$, which vanished after $37 \mathrm{~min}$ forming 7 (cf. Scheme 2 and Scheme 3 ). The integration values are shown below the signals.

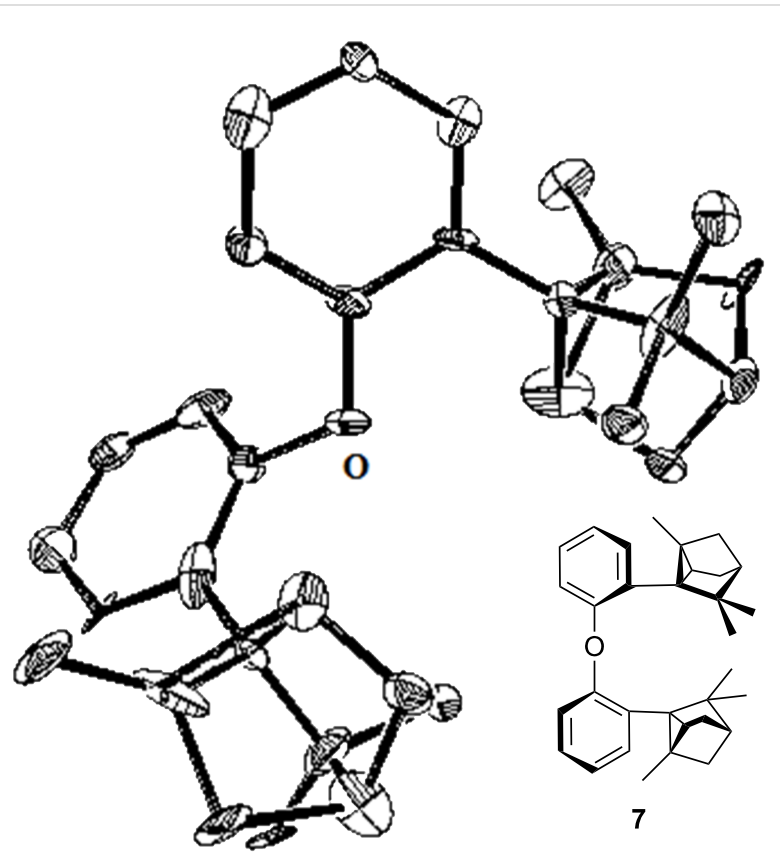

Figure 2: X-ray crystal structure of diphenyl ether-2,2'-biscyclofenchene 7 . Ellipsoids are shown with $50 \%$ probability.
The formation of a cyclopropane ring in 7 can be rationalized to proceed through a fenchyl carbocation (Scheme 3) [34-40]. Intramolecular cyclopropanation reactions are often characterized by prolonged treatment with an acid [41-46]. Stabilization of the intermediate carbocation by the lone pair of the oxygen atom is enabled by lone-pair conjugation (O-lp conjugation) of the benzyl cation and supports elimination of the oxido unit (Scheme 3).

To assess whether this rearrangement, formaing 7 , is mediated by $\mathrm{HCl}$ originating from 3 , chlorine-free O-BIFOP-H (4) was treated with $\mathrm{O}_{2}$, yielding 6 (79\%, Scheme 2). While O-BIFOP-H (4) readily reacts with water, O-BIFOP-(O)H (6) was found to be stable in air and water (Figure 3d). However, addition of $\mathrm{HCl}$ to $\mathrm{O}-\mathrm{BIFOP}-(\mathrm{O}) \mathrm{H}$ (6) gave diphenyl ether2,2'-biscyclofenchene 7 in $65 \%$ yield. Hence, acidic conditions $(\mathrm{HCl})$ are necessary to form 7 from $\mathbf{6}$, which is generated by hydrolysis of 3 (Scheme 2 and Scheme 3).

The analysis of the crystal structure of BIFOP-Cl (1) reveals the large steric demand of the fenchane units, which embed the phosphorus atom, thus making it inaccessible to nucleophilic 

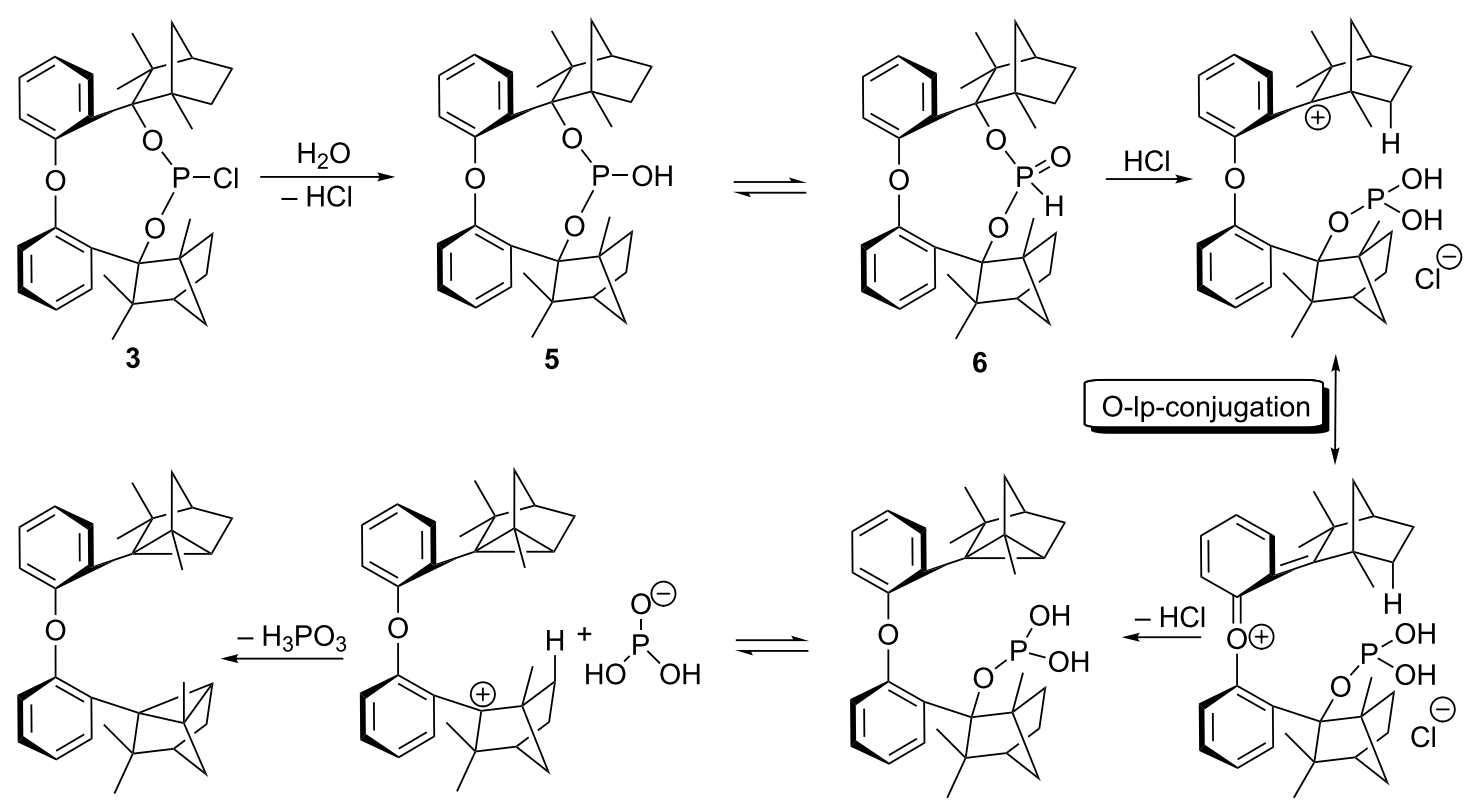

7

Scheme 3: Proposed mechanism for the formation of diphenyl ether-2,2'-biscyclofenchene 7 through stabilization of the intermediate carbocation by $\mathrm{O}-\mathrm{Ip}$ conjugation and cyclopropane formation starting from O-BIFOP-CI (3).

d) after the addition of 1 equiv $\mathrm{H}_{2} \mathrm{O}$

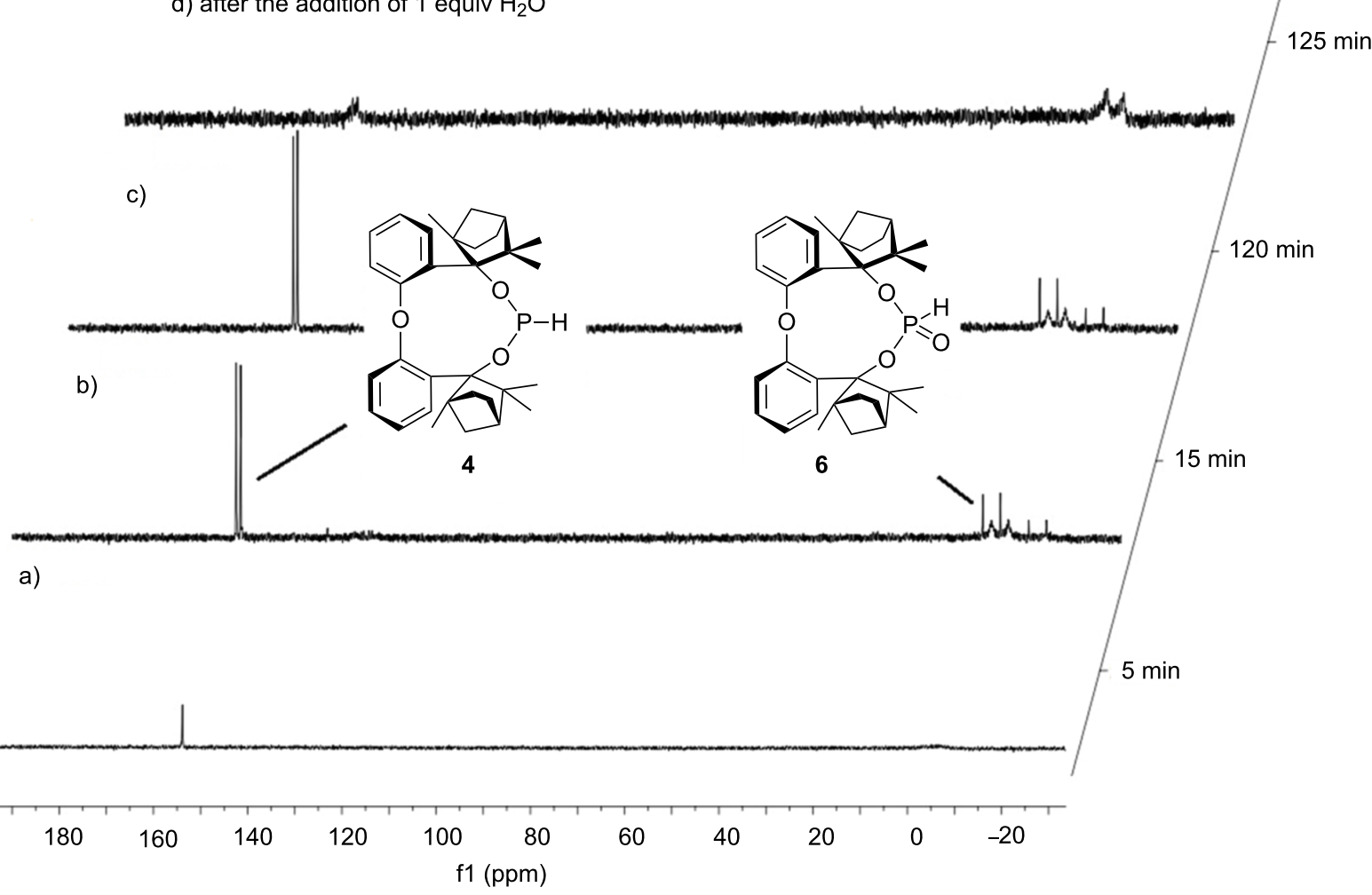

Figure 3: ${ }^{31} \mathrm{P}$ NMR (125 MHz, $\mathrm{CDCl}_{3}$ ) of O-BIFOP-H (4, $\left.\delta=152.5\right)$ adding $\mathrm{O}_{2}$ after a) 5 min; b) 15 min; c) 120 min; d) adding 1 equiv $\mathrm{H}_{2} \mathrm{O}$ forming O-BIFOP-(O)H (6, $\delta=-8.2)$. 


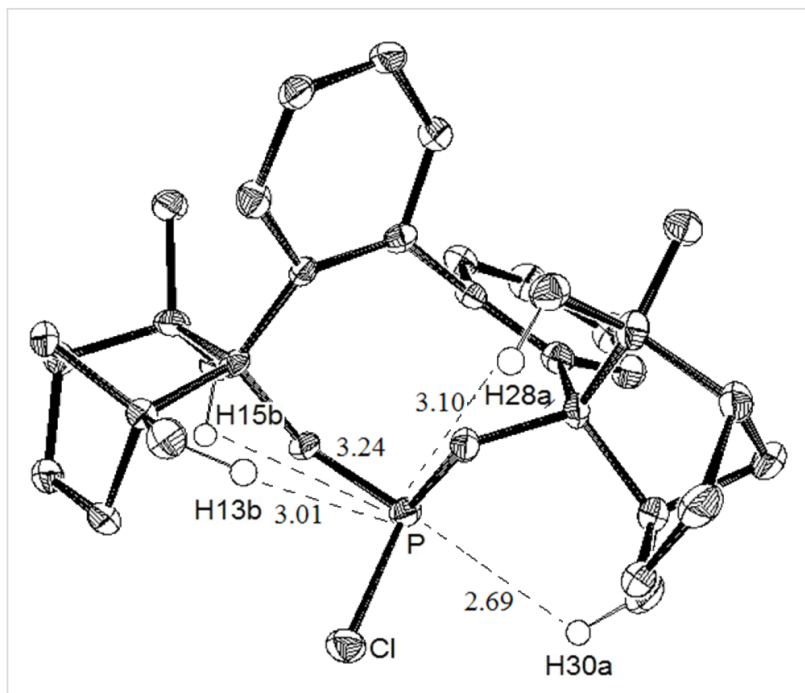

Figure 4: X-ray crystal structure of BIFOP-Cl 1. Ellipsoids are shown with $50 \%$ probability [15].

Table 1: Geometries bases on the X-ray structure of BIFOP-Cla and O-BIFOP-Cl.

$$
\mathrm{BIFOP}-\mathrm{Cl}(\mathbf{1}) \quad \mathrm{O}-\mathrm{BIFOP}-\mathrm{Cl}(\mathbf{3})
$$

\begin{tabular}{lcc}
\hline Angle sum at $P\left({ }^{\circ}\right)^{b}$ & 305.2 & 290.7 \\
FAA-Ip $\left(^{\circ}\right)^{\mathrm{c}}$ & 38.9 & $-26,6$ \\
FAA $\left({ }^{\circ}\right)^{\mathrm{c}}$ & 37.1 & -52.5 \\
$\mathrm{H} 13 \mathrm{~b}-\mathrm{P}(\AA)$ & 3.01 & 4.08 \\
$\mathrm{H} 15 \mathrm{~b}-\mathrm{P}(\AA)$ & 3.24 & 3.42 \\
$\mathrm{H} 28 \mathrm{a}-\mathrm{P}(\AA)$ & 3.10 & 3.20 \\
$\mathrm{H} 30 \mathrm{a}-\mathrm{P}(\AA)$ & 2.69 & 3.06 \\
\hline
\end{tabular}

aPublished in reference [14]. ${ }^{\text {b}}$ Angle sum at phosphorous atom (pyramidality). ${ }^{C}$ Fenchyl-aryl dihedral angles (FAA, C1-C2-C3-O1) on the lone-pair side of phosphorus (FAA-Ip) and at the substituent side (FAA) biaryl axis.

reagents (Figure 4, Table 1) [14,15]. In contrast, the reduced protection of the phosphorus atom in O-BIFOP- $\mathrm{Cl}(3)$, which is primarily caused by the relatively large $\mathrm{H} 13 \mathrm{~b}-\mathrm{P}$ distance $(4.08 \AA$ to $3.01 \AA)$, provides an explanation for the higher reactivity of the $>\mathrm{P}-\mathrm{Cl}$ moiety in $\mathrm{O}-\mathrm{BIFOP}-\mathrm{Cl}(\mathbf{3}$, Scheme 4 , Figure 5, Table 1).

Moreover, the shorter $\mathrm{P}-\mathrm{O}$ distance $(2.4 \AA)$ in $\mathrm{O}-\mathrm{BIFOP}-\mathrm{Cl}$ (3) and the nearly linear $\left(176.5^{\circ}\right) \mathrm{O}-\mathrm{P}-\mathrm{Cl}$ arrangement (Scheme 4) suggest a neighbor-group effect through an O-lp donor to $\sigma^{*} \mathrm{P}-\mathrm{Cl}$ acceptor interaction, supporting chloride substitution (Figure 5, Scheme 4). Hypervalent $\mathrm{P}(\mathrm{III})-\mathrm{O}$ interactions with similar $\mathrm{P}-\mathrm{O}$ distances are documented for five membered rings $[47,48]$ as well as for acyclic systems [49].

The computational analysis of the hydrolysis of the chlorophosphites BIFOP-Cl (1) and O-BIFOP-Cl (3, as well as the

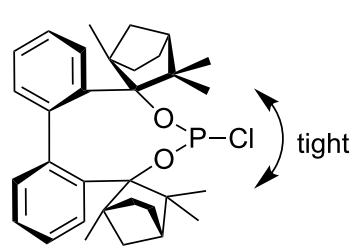

1

less reactive $>\mathrm{P}-\mathrm{Cl}$

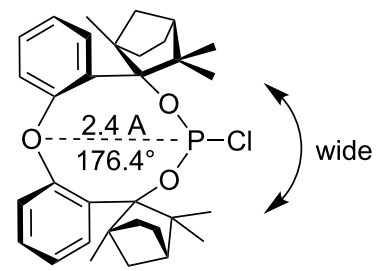

3

more reactive $>\mathrm{P}-\mathrm{Cl}$
Scheme 4: The different backbones provoke different reactivities due to tighter encapsulation of the $\mathrm{P}-\mathrm{Cl}$ unit by the fenchane moieties in $\mathrm{BIFOP}-\mathrm{Cl}$ (1) relative to O-BIFOP-Cl (3).

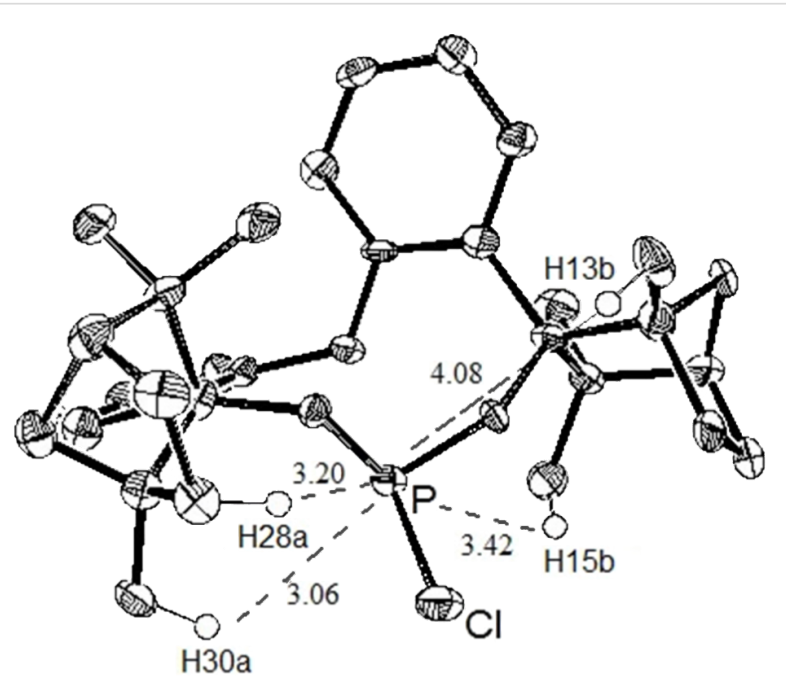

Figure 5: X-ray crystal structure of O-BIFOP-Cl (3). Ellipsoids are shown with $50 \%$ probability.

smaller model system 2-chloro-1,3,2-dioxaphospholane 8) provides further comparison of the $>\mathrm{P}-\mathrm{Cl}$ reactivity. The nucleophilic substitution reaction takes place at a triple-coordinated chlorophosphite (in $\mathrm{R}_{2} \mathrm{PCl}$ ) due to a single-well potential energy surface [50,51]. The initial step of the water addition proceeds through the formation of the transition state (TS1) in which the oxygen atom of the water molecule binds to the phosphorous atom (Scheme 3, Table 2) and chloride substitution forms the product (G2). Here, chloride is replaced at the phosphorus center with the hydroxide nucleophile (Table 2).

The relatively high hydrolyzation barrier of $\mathrm{BIFOP}-\mathrm{Cl}$ $(\mathbf{1}, 31.2 \mathrm{kcal} / \mathrm{mol})$ in comparison to $\mathrm{O}-\mathrm{BIFOP}-\mathrm{Cl}(\mathbf{3}$, $22.5 \mathrm{kcal} / \mathrm{mol})$ and the smaller, glycol-based, chlorophosphite $\left[\mathrm{CH}_{2} \mathrm{O}\right]_{2} \mathrm{P}-\mathrm{Cl}(\mathbf{8}, 18.3 \mathrm{kcal} / \mathrm{mol}$, Table 2$)$ agrees with the experimental finding that $\mathrm{BIFOP}-\mathrm{Cl}(\mathbf{1})$ is unusually robust against hydrolysis (Figure 1 and Figure 3). The lower hydrolysis barriers of $\mathbf{3}$ and $\mathbf{8}$ agree with the expected high reactivity of the $>\mathrm{P}-\mathrm{Cl}$ in water [52-57]. 
Table 2: Computed relative energies $\left(E_{\mathrm{rel}}, \mathrm{kcal} / \mathrm{mol}\right)$ for the reaction of 2, $\mathbf{4}$ or $\mathbf{8}$ with water.

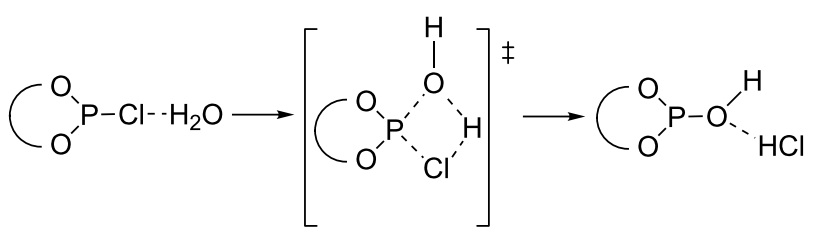

G1

TS1

G2

\begin{tabular}{lllll}
\hline Entry & Chlorophosphane & $E_{\text {rel }}(\mathrm{G} 1)$ & $E_{\text {rel }}(\mathrm{TS} 1)$ & $E_{\text {rel }}(\mathrm{G} 2)$ \\
\hline $1^{\mathrm{a}}$ & $\mathrm{BIFOP}-\mathrm{Cl}(1)$ & 0.0 & 31.2 & -4.7 \\
$2^{\mathrm{a}}$ & O-BIFOP-Cl (3) & 0.0 & 22.5 & -3.1 \\
$3^{\mathrm{b}}$ & {$\left[\mathrm{CH}_{2} \mathrm{O}_{2} \mathrm{P}-\mathrm{Cl}(\mathbf{8})\right.$} & 0.0 & 18.3 & -5.3 \\
\hline
\end{tabular}

aBP86/SVP + ZPE. bMP2/cc-p-VQZ//BP86/SVP + ZPE.

A comparison of the transition state structures of chlorophosphites 1 (Figure 6) and 3 (Figure 7) reveals a higher steric congestion of the $\mathrm{P}-\mathrm{Cl}$ unit by the fenchane moiety in $\mathrm{BIFOP}-\mathrm{Cl}$ (1) relative to $\mathrm{O}-\mathrm{BIFOP}-\mathrm{Cl}$ (3). In BIFOP-Cl (1), the shorter distances of the endo-oriented hydrogen atoms of the fenchane moiety ( $\mathrm{H} 35$ and $\mathrm{H} 75)$ to the $\mathrm{Cl}$ atom of the $\mathrm{P}-\mathrm{Cl}$ unit and to the $\mathrm{O}$ atom of water (Table 3 ) prevent both the elimination of the chloride nucleofuge and the attack of the water nucleophile. This steric congestion of the transition state struc-
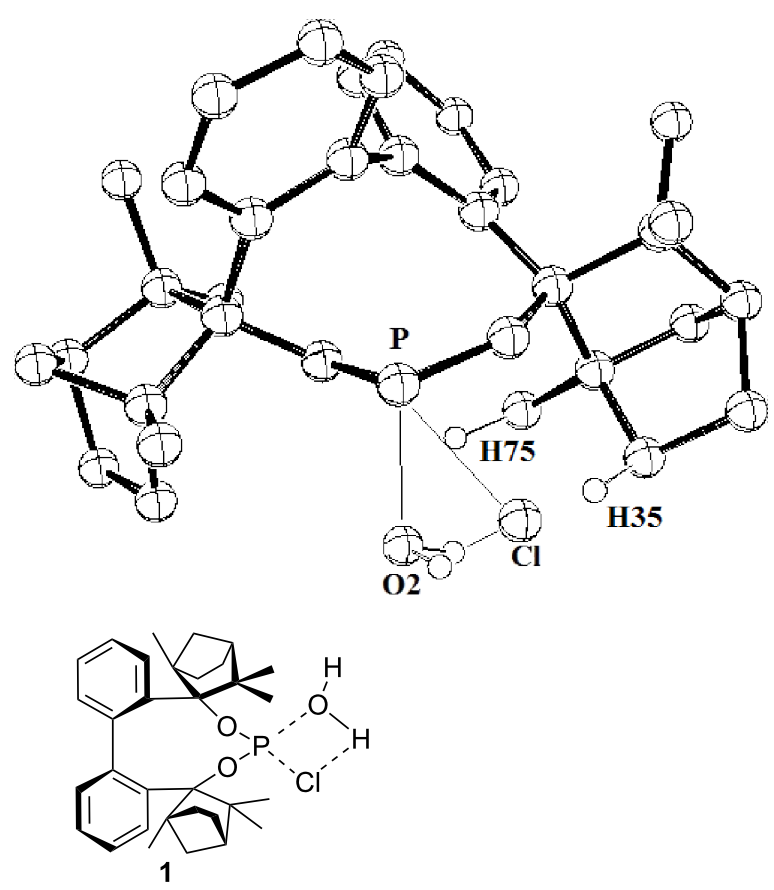

Figure 6: Transition state structure for the reaction of BIFOP-Cl (1) with water (BP86/def-SV(P)).

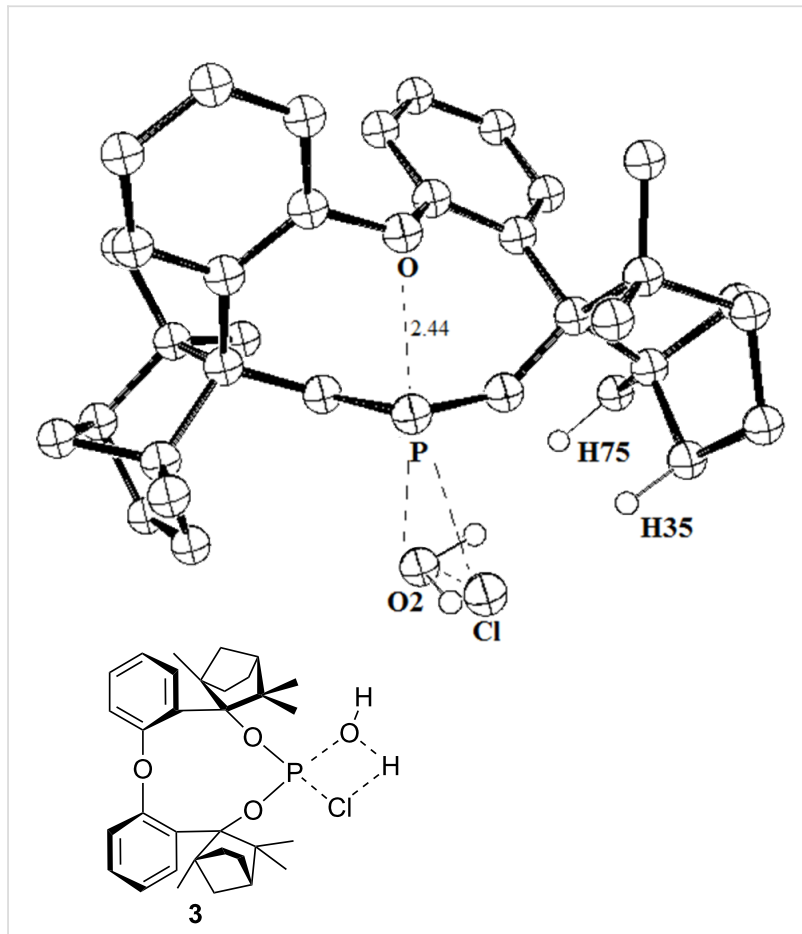

Figure 7: Transition state structure for the reaction of O-BIFOP-Cl (3) with water (BP86/def-SV(P)).

tures in reactions with water explains the surprisingly low reactivity of BIFOP-Cl (1, Figure 6) relative to the much more reactive $\mathrm{O}-\mathrm{BIFOP}-\mathrm{Cl}$ (3, Figure 7).

\section{Conclusion}

Two fenchole-based chlorophosphites, BIFOP-Cl (1) and $\mathrm{O}-\mathrm{BIFOP}-\mathrm{Cl}$ (3), were studied with respect to their striking differences in regards to their reaction with water. While BIFOP-Cl (1) exhibits a surprisingly high stability against 
Table 3: Selected, computed distances in the transition state structures for the addition of water to chlorophosphites 1 and $3 .^{a}$

\begin{tabular}{lcc} 
Distance & BIFOP_Cl (1) & O-BIFOP_Cl (3) \\
\hline $\mathrm{Cl}-\mathrm{H} 35(\AA)$ & 2.65 & 3.05 \\
$\mathrm{Cl}-\mathrm{H} 75(\AA)$ & 4.70 & 5.21 \\
$\mathrm{O} 2-\mathrm{H} 35(\AA)$ & 2.68 & 2.98 \\
$\mathrm{O} 2-\mathrm{H} 75(\AA)$ & 2.60 & 3.36 \\
\hline
\end{tabular}

${ }^{a} B P 86 /$ def-SV(P) optimized transition state structures, cf. Figure 6 and Figure 7.

hydrolysis, O-BIFOP-Cl (3) reacts instantly with water, leading to cyclofenchene 6. X-ray studies revealed that the increased reactivity of the intermediate carbenium ion and cyclopropane formation is due to a steric effect caused by the shielding of the fenchane groups and a hypervalent $\mathrm{P}$ (III)-O interaction. Formation of the cyclofenchene derivative 7 is explained by rearrangement via a 2 -fenchyl carbocation. The DFT computations of the hydrolysis revealed a higher degree of steric congestion in BIFOP-Cl (1) caused by the fenchane units, relative to the less-shielded and hence much more reactive $\mathrm{O}-\mathrm{BIFOP}-\mathrm{Cl}$ (3). This result demonstrates that steric and electronic effects can be used to render the inherently highly reactive and electrophilic phosphorus-halogen units essentially inert against nucleophilic reagents. The stability of BIFOP-Cl (and other phosphorus-halogen systems) against nucleophiles promotes its application as a chiral ligand to be used in, for example, Pd catalysis [13-15].

\section{Experimental}

All reactions were carried out under an inert argon atmosphere and in heated glassware using standard Schlenk techniques. Anhydrous solvents were obtained by distillation from sodium benzophenone ketyl. The NMR spectra were measured with Bruker instruments (Avance II 600, Avance II 300 and DPX Acance 300). Deuterated chloroform was used as solvent. The proton shifts are reported in ppm $(\delta)$ downfield from TMS and are referenced to residual signals of the solvent $\left(\mathrm{CHCl}_{3}\right.$ $7.24 \mathrm{ppm}$ for hydrogen, $77.0 \mathrm{ppm}$ for carbon atoms). The coupling constants $(J)$ are given in Hz. As an external standard, $85 \%$ phosphoric acid was used for the ${ }^{31} \mathrm{P}$ NMR spectra. The infrared spectra were recorded on a Shimadzu, IRAffinity-1 instrument. The wavenumbers $(v)$ of the recorded IR signals are given in $\mathrm{cm}^{-1}$. The $\mathrm{GC}-\mathrm{MS}$ spectra were recorded using an Agilent Technologies, Model GC 6890N gas chromatograph coupled with an HP 5973N series mass selective detector and an HP $7683 \mathrm{GC}$ autosampler. Optical rotation was measured with an IBZ, Messtechnik POLAR L $\mu$ P-WR polarimeter, using a $1 \mathrm{dm}$ path length cell. The reactions were carried out under dry argon. X-ray analysis was performed with a Nonius, Kappa
CCD diffractometer (Mo K $\alpha, \lambda=0.71073$ ). The starting material, O-BIFOL, was obtained in an analogous manner to a procedure previously described [15].

\section{Diphenyl ether-2,2'-bisfencholphosphane chloride (O-BIFOP-Cl, 3)}

The O-BIFOP-Cl compound was prepared in a manner analogous to the procedure described in [15]. $1.48 \mathrm{~mL}$ (3 mmol) of $n$-butyllithium in hexane $(1.6 \mathrm{M})$ was slowly added to a $200 \mathrm{mg}$ solution $(0.42 \mathrm{mmol})$ of O-BIFOL in $1.4 \mathrm{~mL}$ abs. THF at $-20{ }^{\circ} \mathrm{C}$. The mixture was stirred for $30 \mathrm{~min}$ at $-20{ }^{\circ} \mathrm{C}$, then for $1 \mathrm{~h}$ at rt. After again cooling to $-20^{\circ} \mathrm{C}, 0.06 \mathrm{~mL}(0.46 \mathrm{mmol})$ of freshly distilled $\mathrm{PCl}_{3}$ was slowly added and the reaction mixture was stirred for $6 \mathrm{~h}$ at rt. Recrystallization from $\mathrm{Et}_{2} \mathrm{O} /$ $\mathrm{CH}_{2} \mathrm{Cl}_{2}$ resulted in $111 \mathrm{mg}(0.21 \mathrm{mmol}, 50 \%)$ of compound 3 as colorless crystals. $[\alpha]_{\mathrm{D}}{ }^{20}+46.47\left(c 4.5\right.$, hexane); ${ }^{31} \mathrm{P} \mathrm{NMR}$ $\left(125.5 \mathrm{MHz}, \mathrm{CDCl}_{3}\right) \delta 161.9 ;{ }^{1} \mathrm{H}$ NMR $\left(300 \mathrm{MHz}, \mathrm{CDCl}_{3}\right) \delta$ $0.11(\mathrm{~s}, 3 \mathrm{H}), 0.42(\mathrm{~s}, 3 \mathrm{H}), 0.77(\mathrm{~s}, 3 \mathrm{H}), 0.82(\mathrm{~s}, 3 \mathrm{H}), 1.22-1.58$ $(\mathrm{m}, 8 \mathrm{H}), 2.37(\mathrm{~d}, J=9 \mathrm{~Hz}, 1 \mathrm{H}), 2.49(\mathrm{~m}, 3 \mathrm{H}), 2.45(\mathrm{~m}, 3 \mathrm{H})$, $2.76(\mathrm{~m}, 4 \mathrm{H}), 6.75(\mathrm{~d}, J=6 \mathrm{~Hz}, 1 \mathrm{H}), 6.96(\mathrm{t}, J=9 \mathrm{~Hz}, 1 \mathrm{H})$, $7.17-7.22(\mathrm{~m}, 2 \mathrm{H}), 7.54(\mathrm{~d}, J=6 \mathrm{~Hz}, 1 \mathrm{H}), 7.62(\mathrm{~d}, J=6 \mathrm{~Hz}$, $1 \mathrm{H}) ;{ }^{13} \mathrm{C} \mathrm{NMR}\left(75 \mathrm{MHz}, \mathrm{CDCl}_{3}\right) \delta 18.3,21.1,22.2,22.7,32.6$, 38.6, 42.4, 42.9, 49.8, 49.4, 51.3, 52.7, 96.3, 115.2, 121.9, 122.8, 125.6, 128.4, 148.8; X-ray crystal data: $\mathrm{C}_{32} \mathrm{H}_{41} \mathrm{O}_{4} \mathrm{P}$; $M_{\mathrm{r}}=539.1 \mathrm{~g} \cdot \mathrm{mol}^{-1}$; space group: $P 2{ }_{1} 2{ }_{1} 2{ }_{1} ; a=12.2504(6)$, $b=14.9267(9), c=30.6807(12) \AA ; V=5610.2(5) \AA^{3} ; Z=8$; $\rho=1.276 \mathrm{~g} \cdot \mathrm{mL}^{-3} ; T=100(2) \mathrm{K} ; \lambda=0.71073 ; \mu=0.123 \mathrm{~mm}^{-1}$; total reflections: 22204; unique reflections: 11385; observed: 5685 [I $>2 \mathrm{~s}(\mathrm{I})]$; parameters refined: $679 ; \mathrm{R} 1=0.0611, \mathrm{wR} 2=$ $0.0981 ; \mathrm{GOF}=0.924 ; \mathrm{H}$ atoms bound to oxygen were refined, the positions of the $\mathrm{H}$ atoms bound to carbon were calculated.

\section{Diphenyl ether-2,2'-bisfencholphosphane hydride (O-BIFOP-H, 4)}

The O-BIFOP-H compound was prepared in a manner analogous to the procedure as described in [15]. $8.7 \mathrm{mg}(0.23 \mathrm{mmol})$ of $\mathrm{LiAlH}_{4}$ was added to $100 \mathrm{mg}(0.19 \mathrm{mmol})$ of O-BIFOP-Cl (3) in $1 \mathrm{~mL}$ of THF and the mixture was stirred for $3 \mathrm{~h}$ at rt. The solvent was removed in vacuum and the residue was taken up in $10 \mathrm{~mL}$ of toluene and stirred for $30 \mathrm{~min}$ at $\mathrm{rt}$. After filtration through celite to remove $\mathrm{LiCl}$ and other salts, the resulting solution was concentrated in vacuum until precipitation. The recrystallization from toluene yielded $83 \mathrm{mg}(0.16 \mathrm{mmol}, 87 \%)$ of 4 as a white solid. $[\alpha]_{\mathrm{D}}{ }^{20}+53.74$ (c 2.8, hexane); ${ }^{31} \mathrm{P}$ NMR $\left(125.5 \mathrm{MHz}\right.$, toluene- $\left.d_{8}\right) \delta 153.5\left({ }^{1} J_{\mathrm{P}-\mathrm{H}}=190 \mathrm{~Hz}\right) ;{ }^{1} \mathrm{H} \mathrm{NMR}$ (300 MHz, toluene- $\left.d_{8}\right) \delta 0.35(\mathrm{~s}, 3 \mathrm{H}), 0.55(\mathrm{~s}, 3 \mathrm{H}), 0.73(\mathrm{~s}, 3 \mathrm{H})$, $0.96(\mathrm{t}, J=6 \mathrm{~Hz}, 1 \mathrm{H}), 1.04-1.11(\mathrm{~m}, 6 \mathrm{H}), 1.22(\mathrm{~s}, 3 \mathrm{H}), 1.31(\mathrm{t}$, $J=6 \mathrm{~Hz}, 1 \mathrm{H}), 1.52(\mathrm{~d}, J=6 \mathrm{~Hz}, 2 \mathrm{H}), 1.68(\mathrm{~s}, 1 \mathrm{H}), 1.72(\mathrm{~s}, 1 \mathrm{H})$, $6.62\left(\mathrm{~d},{ }^{1} J_{\mathrm{P}-\mathrm{H}}=190 \mathrm{~Hz}, 1 \mathrm{H}\right), 6.84-7.03(\mathrm{~m}, 2 \mathrm{H}), 7.53(\mathrm{~d}, J=6$ $\mathrm{Hz}, 1 \mathrm{H}) ;{ }^{13} \mathrm{C}$ NMR $\left(75 \mathrm{MHz}\right.$, toluene- $\left.d_{8}\right) \delta 18.3,22.8,23.8$, 24.1, 24.8, 23.2, 34.4, 42.4, 43.5, 49.5, 52.4, 54.6, 97.9, 99.3, 
$116.9,118.2,122.5,122.8,123.9,124.5,125.0,126.1,136.8$, $138.8,145.2,149.7$.

\section{Diphenyl ether-2,2'-bisfencholphosphate (O-BIFOPH $(\mathrm{O}), 6)$}

$\mathrm{O}_{2}$ was supplied to $83 \mathrm{mg}(0.16 \mathrm{mmol})$ of O-BIFOP-H (4) for $5 \mathrm{~min}$. The recrystallization from toluene yielded $38 \mathrm{mg}(79 \%)$ of 6 as a colorless solid. $[\alpha]_{\mathrm{D}}{ }^{20}+55.7$ (c 4.5; hexane); ${ }^{31} \mathrm{P} \mathrm{NMR}$ $\left(125.5 \mathrm{MHz}\right.$, toluene- $\left.d_{8}\right) \delta-8.2\left({ }^{1} J_{\mathrm{P}-\mathrm{H}}=710.8 \mathrm{~Hz}\right) ;{ }^{1} \mathrm{H}$ NMR $\left(300 \mathrm{MHz}, \mathrm{CDCl}_{3}\right) \delta 0.41(\mathrm{~s}, 3 \mathrm{H}), 0.52(\mathrm{~s}, 3 \mathrm{H}), 0.57(\mathrm{~s}, 3 \mathrm{H})$, $0.82(\mathrm{~s}, 3 \mathrm{H}), 1.04(\mathrm{~s}, 1 \mathrm{H}), 1.20(\mathrm{~s}, 1 \mathrm{H}), 1.28(\mathrm{~s}, 6 \mathrm{H}), 1.34(\mathrm{~m}$, $6 \mathrm{H}), 1.37(\mathrm{~m}, 6 \mathrm{H}), 1.49(\mathrm{~s}, 4 \mathrm{H}), 1.65(\mathrm{~d}, J=9 \mathrm{~Hz}, 2 \mathrm{H}), 1.75(\mathrm{~m}$, $4 \mathrm{H}), 6.75\left(\mathrm{~d},{ }^{1} J_{\mathrm{P}-\mathrm{H}}=710.8 \mathrm{~Hz}, 1 \mathrm{H}\right), 6.96(\mathrm{~d}, J=6 \mathrm{~Hz}, 1 \mathrm{H})$, $7.17(\mathrm{t}, J=9 \mathrm{~Hz}, 2 \mathrm{H}), 6.64(\mathrm{~d}, J=6 \mathrm{~Hz}, 1 \mathrm{H}), 7.71(\mathrm{~d}, J=6 \mathrm{~Hz}$, $1 \mathrm{H}) ;{ }^{13} \mathrm{C} \mathrm{NMR}\left(75 \mathrm{MHz}, \mathrm{CDCl}_{3}\right) \delta 18.03,18.17,21.90,22.97$, $23.63,23.73,28.62,29.69,34.31,35.60,41.02,42.33,43.06$, $48.73,49.04,49.31,50.30,55.60,118.05,119.87,121.08$, $121.69,122.93,123.36,126.58,127.82,128.20,129.97,130.55$, 131.46 .

\section{Diphenyl ether-2,2'-biscyclofenchene-1,3,3- trimethyltricyclo[2.2.1.0]heptane (7)}

$2.9 \mathrm{~mL}(0.16 \mathrm{mmol})$ of $\mathrm{H}_{2} \mathrm{O}$ was slowly added to $83 \mathrm{mg}$ of O-BIFOP-Cl $(3,0.16 \mathrm{mmol})$ in $2 \mathrm{~mL}$ of THF, and the mixture was stirred for $20 \mathrm{~min}$ at $\mathrm{rt}$. The solvent was removed in vacuum, and the residue was taken up in $10 \mathrm{~mL}$ of toluene and filtered through celite. The resulting solution was concentrated in vacuum until precipitation. The recrystallization from toluene yielded $44 \mathrm{mg}(65 \%)$ of 7 as colorless crystals. ${ }^{1} \mathrm{H}$ NMR $\left(300 \mathrm{MHz} \mathrm{CDCl}_{3}\right) \delta 0.74(\mathrm{~s}, 1 \mathrm{H}), 0.90(\mathrm{~s}, 3 \mathrm{H}), 0.94(\mathrm{~s}, 3 \mathrm{H})$, $1.07(\mathrm{~s}, 1 \mathrm{H}), 1.12(\mathrm{~s}, 3 \mathrm{H}), 1.24-1.29(\mathrm{~m}, 3 \mathrm{H}), 1.46(\mathrm{~s}, 1 \mathrm{H}), 1.53$ $(\mathrm{d}, J=10 \mathrm{~Hz}, 2 \mathrm{H}), 1.84(\mathrm{~d}, J=10 \mathrm{~Hz}, 2 \mathrm{H}), 6.89$ (d, $J=6 \mathrm{~Hz}$, $1 \mathrm{H}), 6.99(\mathrm{t}, J=9 \mathrm{~Hz}, 1 \mathrm{H}), 7.09(\mathrm{~d}, J=6 \mathrm{~Hz}, 1 \mathrm{H}), 7.19$ (d, $J=$ $6 \mathrm{~Hz}, 1 \mathrm{H}) ;{ }^{13} \mathrm{C} \mathrm{NMR}\left(75 \mathrm{MHz}, \mathrm{CDCl}_{3}\right) \delta 15.63,15.90,21.76$, $22.23,22.61,25.86,27.09,32.72,33.04,35.68,38.20,38.33$, 42.61, 42.72, 47.65, 47.81, 118.62, 120.29, 121.47, 121.86, 126.86, 127.40, 127.91, 134.34, 134.69; IR (KBr) v: 3334 (s), 2987 (vs), 1503 (m), 1434 (m); ESIMS (\%) m/z: [M] 438.3; Anal. calcd for $\mathrm{C}_{32} \mathrm{H}_{38} \mathrm{O}\left(438.3 \mathrm{~g} \cdot \mathrm{mol}^{-1}\right)$ : C, 87.62; $\mathrm{H}, 8.73$; found: C, 87.60; $\mathrm{H}, 9.19$. X-ray crystal data: $\mathrm{C}_{32} \mathrm{H}_{38} \mathrm{O}$; $M_{\mathrm{r}}=438.6 \mathrm{~g} \cdot \mathrm{mol}^{-1}$; space group: $P 2_{1} ; a=7.2593(6)$, $b=16.903(2), c=20.472(2) \AA ; V=2508.4(4) \AA^{3} ; Z=4$; $\rho=1.161 \mathrm{~g} \cdot \mathrm{mL}^{-3} ; T=100(2) \mathrm{K} ; \lambda=0.71073 ; \mu=0.068 \mathrm{~mm}^{-1}$; total reflections: 10449; unique reflections: 8172 ; observed: 3859 [I $>2$ s(I)]; parameters refined: $578 ; \mathrm{R} 1=0.1649$, wR2 $=$ $0.3899 ; \mathrm{GOF}=1.264 ; \mathrm{H}$ atoms bound to oxygen were refined, the positions of the $\mathrm{H}$ atoms bound to carbon were calculated.

\section{Computational details}

The computations were performed with the program package TURBOMOLE-5.10 [58-60]. The employed functional was
BP86 with an $\mathrm{m} 3$ grid size combined with the contracted, SVP basis set from Ahlrichs et al. The resolution-of-identity approximation for a two-electron integral evaluation was used. All stationary points were fully optimized and confirmed by separate analytical frequency calculations. The transition state structures were optimized with quasi-Newton-Raphson methods by using the Powell update algorithm for Hessian matrix approximation (analytical frequency calculation subsequent). The absolute energies were zero-point-corrected with the vibrational information resulting from the harmonic analytical frequency calculations.

\section{Acknowledgements}

We are grateful to the Funds der Chemischen Industrie for financial support. We also thank the Regionales Rechenzentrum zu Köln (RRZK) for the maintenance of the HPC systems, and Bayer AG, BASF AG, Wacker AG, Evonic AG, Raschig $\mathrm{GmbH}$, Symrise $\mathrm{GmbH}$, Solvay $\mathrm{GmbH}$ and the OMG group for their generous support.

\section{References}

1. Brunel, J. M. Chem. Rev. 2005, 105, 857. doi:10.1021/cr040079g

2. van Leeuwen, P. W. N. M.; Kamer, P. C. J.; Claver, C.; Pàmies, O.; Dièguez, M. Chem. Rev. 2011, 111, 2077. doi:10.1021/cr1002497

3. Fernàndez-Pèrez, H.; Etayo, P.; Panossian, A.; Vidal-Ferran, A. Chem. Rev. 2011, 111, 2119. doi:10.1021/cr100244e

4. Seebach, D.; Beck, A. K.; Heckel, A. Angew. Chem. 2001, 113, 96. doi:10.1002/1521-3757(20010105)113:1<96::AID-ANGE96>3.0.CO;2B

Angew. Chem., Int. Ed. 2001, 40, 92.

doi:10.1002/1521-3773(20010105)40:1<92::AID-ANIE92>3.0.CO;2-K

5. Teichert, J. F.; Feringa, B. L. Angew. Chem. 2010, 122, 2538. doi:10.1002/ange.200904948

Angew. Chem., Int. Ed. 2010, 49, 2486. doi:10.1002/anie.200904948

6. Schober, K.; Hartmann, E.; Zhang, H.; Gschwind, R. M. Angew. Chem. 2010, 122, 2855. doi:10.1002/ange.200907247

Angew. Chem., Int. Ed. 2010, 49, 2794. doi:10.1002/anie.200907247

7. Shibasaki, M.; Sasai, H.; Arai, T. Angew. Chem. 1997, 109, 1290. doi:10.1002/ange.19971091204

Angew. Chem., Int. Ed. Engl. 1997, 36, 1236.

doi:10.1002/anie.199712361

8. Sasai, H.; Arai, T.; Satow, Y.; Houk, K. N.; Shibasaki, M. J. Am. Chem. Soc. 1995, 117, 6194. doi:10.1021/ja00128a005

9. d'Augustin, M.; Palais, L.; Alexakis, A. Angew. Chem. 2005, 117, 1400. doi:10.1002/ange.200462137 Angew. Chem., Int. Ed. 2005, 44, 1376. doi:10.1002/anie.200462137

10. Ackermann, L.; Kapdi, A. R.; Schulzke, C. Org. Lett. 2010, 12, 2298. doi:10.1021/ol100658y

11. Puckette, T. A. Chem. Ind. 2007, 115, 31

12. Timosheva, N. V.; Chandrasekaran, A.; Holmes, R. R. J. Am. Chem. Soc. 2005, 127, 12474. doi:10.1021/ja053422n

13. Blanco Trillo, R.; Leven, M.; Neudörfl, J. M.; Goldfuss, B. Adv. Synth. Catal. 2012, 354, 1451. doi:10.1002/adsc.201100924

14. Goldfuss, B.; Löschmann, T.; Kop-Weiershausen, T.; Neudörfl, J.; Rominger, F. Beilstein J. Org. Chem. 2006, 2, No. 7. doi:10.1186/1860-5397-2-7 
15. Kop-Weiershausen, T.; Lex, J.; Neudörfl, J.-M.; Goldfuss, B. Beilstein J. Org. Chem. 2005, 1, No. 6. doi:10.1186/1860-5397-1-6

16. Lange, D. A.; Neudörfl, J.-M.; Goldfuss, B. Tetrahedron 2006, 62, 3704. doi:10.1016/j.tet.2006.01.060

17. Soki, F.; Neudörfl, J.-M.; Goldfuss, B. J. Organomet. Chem. 2008, 693, 2139. doi:10.1016/j.jorganchem.2008.03.013

18. Goldfuss, B.; Löschmann, T.; Rominger, F. Chem. - Eur. J. 2001, 7, 2028.

doi:10.1002/1521-3765(20010504)7:9<2028::AID-CHEM2028>3.0.CO; $2-Y$

19. Goldfuss, B.; Rominger, F. Tetrahedron 2000, 56, 881. doi:10.1016/S0040-4020(99)01077-7

20. Goldfuss, B.; Eisenträger, E. Aust. J. Chem. 2000, 53, 209. doi:10.1071/CH99184

21. Goldfuss, B.; Löschmann, T.; Rominger, F. Chem. - Eur. J. 2004, 10, 5422. doi:10.1002/chem.200400273

22. Soki, F. Synthese und Charakterisierung neuartiger Fencholate und deren Einsatz als Chiralitätsvermittler in enantioselktiven $\mathrm{C}-\mathrm{C}$ Knüpfungsreaktionen. Ph.D. Thesis, University of Cologne, Germany, 2008.

23. Steigelmann, M.; Nisar, Y.; Rominger, F.; Goldfuss, B. Chem. - Eur. J. 2002, 8, 5211.

doi:10.1002/1521-3765(20021115)8:22<5211::AID-CHEM5211>3.0.C O;2-S

24. Goldfuss, B.; Steigelmann, M.; Rominger, F. Eur. J. Org. Chem. 2000, 1785.

doi:10.1002/(SICI)1099-0690(200005)2000:9<1785::AID-EJOC1785>3 .0.CO;2-0

25. Goldfuss, B.; Steigelmann, M. J. Mol. Model. 2000, 6, 166. doi:10.1007/s0089400060166

26. Leven, M.; Schlörer, N. E.; Neudörfl, J. M.; Goldfuss, B. Chem. - Eur. J. 2010, 16, 13443. doi:10.1002/chem.201001106

27. Gliga, A.; Klare, H.; Schumacher, M.; Soki, F.; Neudörfl, J. M.; Goldfuss, B. Eur. J. Org. Chem. 2011, 256-263. doi:10.1002/ejoc.201001295

28. Goldfuss, B.; Steigelmann, M.; Khan, S. I.; Houk, K. N. J. Org. Chem. 2000, 65, 77. doi:10.1021/j0991070v

29. Goldfuss, B.; Khan, S. I.; Houk, K. N. Organometallics 1999, 18, 2927. doi:10.1021/om990184u

30. Goldfuss, B. Synthesis 2005, 2271. doi:10.1055/s-2005-872107

31. Goldfuss, B.; Steigelmann, M.; Löschmann, T.; Schilling, G.; Rominger, F. Chem. - Eur. J. 2005, 11, 4019. doi:10.1002/chem.200500158

32. Goldfuss, B.; Steigelmann, M.; Rominger, F.; Urtel, H. Chem. - Eur. J. 2001, 7, 4456.

doi:10.1002/1521-3765(20011015)7:20<4456::AID-CHEM4456>3.0.C O;2-S

33. Goldfuss, B.; Steigelmann, M.; Rominger, F. Angew. Chem. 2000, 112, 4299.

doi:10.1002/1521-3757(20001117)112:22<4299::AID-ANGE4299>3.0. CO;2-O

Angew. Chem., Int. Ed. 2000, 39, 4133.

doi:10.1002/1521-3773(20001117)39:22<4133::AID-ANIE4133>3.0.CO ;2-X

34. Huang, E.; Ranganayakulu, K.; Sorensen, T. S. J. Am. Chem. Soc. 1972, 94, 1779. doi:10.1021/ja00760a079

35. Sorensen, T. S. Acc. Chem. Res. 1976, 9, 257. doi:10.1021/ar50103a003

36. Starling, S. M.; Vonwiller, S. C.; Reek, J. N. H. J. Org. Chem. 1998, 63, 2262. doi:10.1021/jo972025v
37. Brown, H. C.; Takeuchi, K. J. Am. Chem. Soc. 1968, 90, 2693. doi:10.1021/ja01012a043

38. Farnum, D. G.; Mehta, G. J. Am. Chem. Soc. 1969, 91, 3256. doi:10.1021/ja01040a028

39. Brown, H. C.; Takeuchi, K.; Ravindranathan, M. J. Am. Chem. Soc. 1977, 99, 2684. doi:10.1021/ja00450a047

40. Farnum, D. G.; Wolf, A. D. J. Am. Chem. Soc. 1974, 96, 5166. doi:10.1021/ja00823a025

41. von Ragué Schleyer, P.; Lam, L. K. M.; Raber, D. J.; Fry, J. L.; McKervey, M. A.; Alford, J. R.; Cuddy, B. D.; Keizer, V. G.; Geluk, H. W.; Schlatmann, J. L. M. A. J. Am. Chem. Soc. 1970, 92, 5246. doi:10.1021/ja00720a056

42. Majerski, Z.; von Ragué Schleyer, P.; Wolf, A. P. J. Am. Chem. Soc. 1970, 92, 5731. doi:10.1021/ja00722a034

43. Nickon, A.; Weglein, R. C. J. Am. Chem. Soc. 1975, 97, 1271. doi:10.1021/ja00838a067

44. Paquette, L. A.; Waykole, L.; Jendralla, H.; Cottrell, C. E. J. Am. Chem. Soc. 1986, 108, 3739. doi:10.1021/ja00273a031

45. Paquette, L. A.; Lanter, J. C.; Johnston, J. N. J. Org. Chem. 1997, 62, 1702. doi:10.1021/jo962019j

46. Lee, O.-S.; Yang, K.; Kang, K. D.; Koo, I. S.; Kim, C.-K.; Lee, I. J. Comput. Chem. 2004, 25, 1740. doi:10.1002/jcc.20104

47. Milov, A. A.; Minyaev, R. M.; Minkin, V. I. J. Phys. Chem. A 2011, 115, 12973. doi:10.1021/jp2042119

48. Kubo, K.; Nakazawa, H.; Kawamura, K.; Mizuta, T.; Miyoshi, K. J. Am. Chem. Soc. 1998, 120, 6715. doi:10.1021/ja980146m

49. Dobado, J. A.; Martinez-Garcia, H.; Molina, J.; Sundberg, M. R. J. Am. Chem. Soc. 2000, 122, 1144. doi:10.1021/ja992672z

50. van Bochove, M. A.; Swart, M.; Bickelhaupt, F. M. Phys. Chem. Chem. Phys. 2009, 11, 259. doi:10.1039/b813152j

51. van Bochove, M. A.; Swart, M.; Bickelhaupt, F. M. ChemPhysChem 2007, 8, 2452. doi:10.1002/cphc. 200700488

52. Koh, H. J.; Kang, S. J.; Kevill, D. N. Phosphorus, Sulfur Silicon Relat. Elem. 2010, 185, 1404. doi:10.1080/10426500903061525

53. Koh, H. J.; Kevill, D. N. Phosphorus, Sulfur Silicon Relat. Elem. 2010, 185, 865. doi:10.1080/10426500903012478

54. Koh, H. J.; Kang, S. J.; Kevill, D. N. Phosphorus, Sulfur Silicon Relat. Elem. 2008, 183, 364. doi:10.1080/10426500701734943

55. Kevill, D. N.; Koh, H. J. J. Phys. Org. Chem. 2007, 20, 88. doi:10.1002/poc.1124

56. Kevill, D. N.; Carver, J. S. Org. Biomol. Chem. 2004, 2, 2040. doi:10.1039/b402093f

57. Kevill, D. N.; Miller, B. J. Org. Chem. 2002, 67, 7399. doi:10.1021/jo020467n

58. Ahlrichs, R.; Bär, M.; Häser, M.; Horn, H.; Kölmel, C. Chem. Phys. Lett. 1989, 162, 165. doi:10.1016/0009-2614(89)85118-8

59. Staroverov, V. N.; Scuseria, G. E.; Tao, J.; Perdew, J. P. J. Chem. Phys. 2003, 119, 12129. doi:10.1063/1.1626543

60. Schäfer, A.; Horn, H.; Ahlrichs, R. J. Chem. Phys. 1992, 97, 2571. doi:10.1063/1.463096 


\section{License and Terms}

This is an Open Access article under the terms of the Creative Commons Attribution License

(http://creativecommons.org/licenses/by/2.0), which permits unrestricted use, distribution, and reproduction in any medium, provided the original work is properly cited.

The license is subject to the Beilstein Journal of Organic Chemistry terms and conditions:

(http://www.beilstein-journals.org/bjoc)

The definitive version of this article is the electronic one which can be found at:

doi:10.3762/bjoc. 11.36 